\title{
Characterization of Insulin-Like Growth Factor I Receptors on Madin-Darby Canine Kidney (MDCK) Cell Line
}

\author{
Izumi SUKEGAWA, Naomi HIZUKA, Kazue TAKANO, \\ KUMIKo ASAKAWA and KaZUo SHIZUME
}

\author{
Department of Medicine \\ Institute of Clinical Endocrinology \\ Tokyo Women's Medical College, Tokyo 162, Japan
}

\begin{abstract}
Specific insulin-like growth factor I (IGF-I) receptors on the Madin-Darby canine kidney (MDCK) cell line were identified and characterized. [ $\left.{ }^{125} \mathrm{I}\right] \mathrm{IGF}-\mathrm{I}$ specifically bound to the cells, but $\left[{ }^{125} I\right]$ insulin bindings to the cells was minimal. Unlabeled IGF-I displaced both the IGF-I and insulin bindings with potencies that were 100 and 10 times as great as insulin. By an affinity labeling technique, IGF type I receptors were present in the MDCK cells. IGF-I stimulated DNA synthesis and cell proliferation at physiological concentrations. On the other hand, insulin had a little effect on DNA synthesis. These data suggest that IGF type I receptors as demonstrated in MDCK cells are involved in DNA synthesis and cell proliferation.
\end{abstract}

Specific receptors for insulin-like growth factor (IGF) and insulin are located on the cell membrane of a variety of cells (Nissley and Rechler, 1984) and both receptors coexist in most cells. Both hormones have similar biological activities and it is known that each hormone can bind to the receptor of the other.

The MDCK cell line, established from dog kidney (Madin and Darby, 1958), has the morphological properties of distal tub-

\footnotetext{
Received June 19, 1986

Please address all correspondence to:

Dr. Izumi Sukegawa

Department of Medicine,

Institute of Clinical Endocrinology

Tokyo Women's Medical College

8-1 Kawada-cho, Shinjuku-ku

Tokyo, 162, Japan
}

ular epithelial cells (Rindler et al., 1979; Boerner and Saier, 1985) and it also possesses some functional properties similar to those of normal kidney (Lin et al., 1982 and 1985; Bechner et al., 1985). While insulin-like effects were produced in this cell line by insulin mimickers, such as concanavalin A and wheat germ agglutinin (Roth et al., 1981), Hofmann et al., (1985) reported that insulin receptors were not present in the MDCK cell line. Recently, Krett et al., (1986) reported that IGF type I and II receptors were present in the cell line.

In the present study, we have characterized IGF-I receptors on the MDCK cell line and investigated its mitogenic effects on the cells. 


\section{Materials and Methods}

\section{Cells}

Cultured MDCK cell line (originally from the American Type Culture Collection) was provided by Dr. Nakajima, of the Institute of Medical Science, University of Tokyo. The cells were grown at $37^{\circ} \mathrm{C}$ in Dulbecco's modified Eagle's medium (DMEM) containing $10 \%$ fetal calf serum (FCS) under $5 \% \mathrm{CO}_{2}-95 \%$ air atmosphere.

\section{Hormones and reagents}

IGF-I was kindly provided by Fujisawa Pharmaceutical Co. (Osaka, Japan). The IGF-I preparation was synthesized by recombinant DNA technology as described (Niwa et al., 1986), and the amino acid sequence of the preparation is the same as that of natural IGF-I. Crystalline porcine insulin was a gift from Eli Lilly Co. (Indianapolis, IN). Multiplication stimulating activity (MSA) was purchased from Collaborative Research (Lexington, MA), and ${ }^{125} \mathrm{INa}$ and $\left[{ }^{3} \mathrm{H}\right]$ thymidine from New England Nuclear (Boston, MA). IGF-I and insulin were iodinated by a chloramine-T method modified as reported (Zapf et al., 1975: Roth, 1975) with a specific activity of $180 \mu \mathrm{Ci} / \mu \mathrm{g}$ and $100 \mu \mathrm{Ci} / \mu \mathrm{g}$, respectively.

\section{Binding studies for IGF-I and insulin}

The subconfluent MDCK cells were washed with phosphate-buffered saline (PBS) and incubated for detachment with $0.02 \%$ EDTA and $0.05 \%$ trypsin for $10 \mathrm{~min}$ at $37^{\circ} \mathrm{C}$. The cells were suspended in assay buffer (Buffer G) (Gambhir et al., 1978) and incubated with [125I]IGF-I (0.15$0.2 \mathrm{ng} / \mathrm{ml}$ ) in the presence or absence of IGF-I in a total volume of $0.5 \mathrm{ml}$. At the end of the incubation, replicate $200 \mu \mathrm{l}$ aliquots were layered onto ice-cold buffer and centrifuged for $2 \mathrm{~min}$ at $8000 \times \mathrm{g}$ in a Beckman B microfuge (Beckman, Palo Alto, CA). After aspirating the supernatant, cell-associated radioactivity was counted in a $\gamma$-spectrometer. Nonspecific binding was defined as cell-associated radioactivity in the presence of an excess of unlabeled IGF-I $(1 \mu \mathrm{g} /$ $\mathrm{ml}$ ). Specific binding is the difference between total binding and nonspecific binding. The binding study for insulin was carried out similarly to that for IGF-I.

\section{$\left[{ }^{3} H\right]$ Thymidine incorporation into DNA}

The cells $\left(0.4 \times 10^{5}\right.$ cells $\left./ \mathrm{ml}\right)$ were plated to multi-well dishes supplemented with DMEM containing 10\% FCS and incubated for $24 \mathrm{~h}$, and then the cells $\left(1 \times 10^{5}\right.$ cells $\left./ \mathrm{ml}\right)$ were cultured in serum-free DMEM containing $0.25 \%$ bovine serum albumin (BSA) for $24 \mathrm{~h}$ at $37^{\circ} \mathrm{C}$. The cells were incubated with or without IGF-I and/or insulin for $18 \mathrm{~h}$ at $37^{\circ} \mathrm{C}$, followed by the pulse with $\left[{ }^{3} \mathrm{H}\right]$ thymidine $(0.5 \mu \mathrm{Ci})$ for $1 \mathrm{~h}$ at $37^{\circ} \mathrm{C}$. The cells were washed twice with ice-cold PBS with $0.25 \%$ BSA, and the trichloroacetic acid (TCA) precipitable $\left[{ }^{3} \mathrm{H}\right]$ thymidine was counted in a scintillation spectrometer.

\section{Cell proliferation}

MDCK cells were plated as described above, and then the cells were washed twice with DMEM containing $1 \%$ FCS and incubated with IGF-I $(0-100 \mathrm{ng} / \mathrm{ml})$. The number of cells was counted every day with a Coulter Counter (Coulter Electronics, Hialeath, FL).

\section{Cross-linking of $\left.{ }^{125} I\right] I G F-I$ with MDCK cells}

The MDCK cells $\left(4 \times 10^{7}\right.$ cells $\left./ \mathrm{ml}\right)$ were incubated in $50 \mathrm{mM} \mathrm{N}$-2-hydroxyethyl-piperazine$\mathrm{N}^{\prime}$-2-ethanesulfonic acid (HEPES) lymphocyte buffer (Eastman et al. 1979) with $0.1 \%$ BSA at $4^{\circ} \mathrm{C}$ overnight with $\left.{ }^{[25} \mathrm{I}\right] \mathrm{IGF}-\mathrm{I}$ in the presence or absence of unlabeled IGF-I $(1 \mu \mathrm{g} / \mathrm{ml})$. The cells were washed in ice-cold buffer without BSA and resuspended in the same buffer. Disuccinimidyl suberate (DSS), dissolved in dimethyl sulfoxide, was added at a final concentration of $1 \mathrm{mM}$. After $30 \mathrm{~min}$, the reaction was stopped by $10 \mathrm{mM}$ Tris-(hydroxymethyl) aminomethane and $1 \mathrm{mM}$ EDTA. The cells were solubilized in $50 \mathrm{mM}$ HEPES buffer containing 1\% Triton $\mathrm{X}-100,0.15 \mathrm{M} \mathrm{NaCl}$ and $2 \mathrm{mM}$ phenylmethylsulfonyl fluoride for one hour at $4^{\circ} \mathrm{C}$ and centrifuged at $100,000 \times \mathrm{g}$ for $45 \mathrm{~min}$. The supernatant was precipitated with ice-cold $10 \%$ TCA and the pellet was boiled for $5 \mathrm{~min}$ in $2 \%$ sodium dodecyl sulfate (SDS), $10 \%(\mathrm{v} / \mathrm{v})$ glycerol, $0.5 \mathrm{M}$ 2-mercaptoethanol, $0.01 \%$ bromophenol blue and $10 \mathrm{mM}$ sodium phosphate buffer, $\mathrm{pH}$ 7.0. Samples were analyzed by SDS/polyacrylamide gel electrophoresis (PAGE) according to Laemmli (1970). Autoradiography was carried out using Kodak X-Omat film with an intensifying screen. 


\section{Results}

Binding of $\left[{ }^{125} I\right] I G F-I$ to $M D C K$ cells

[ ${ }^{125}$ I]IGF-I specifically bound to the MDCK cells, and the binding increased linearly as a function of the concentration. The binding of [ ${ }^{125}$ I]IGF-I to the cells was also time- and temperature-dependent (Fig. 1). At $4^{\circ} \mathrm{C}$, the binding reached a plateau by $24 \mathrm{~h}$, and the maximal binding was greater than that at $37^{\circ} \mathrm{C}$ or $15^{\circ} \mathrm{C}$. Binding studies were therefore performed at $4^{\circ} \mathrm{C}$ for $24 \mathrm{~h}$. At a cell concentration of $6 \times 10^{6}$ cells $/ \mathrm{ml}$, the specific binding of [ $\left.{ }^{125} \mathrm{I}\right]$ IGF-I averaged $12 \%$ of the total [ ${ }^{125}$ I]IGF-I ad-

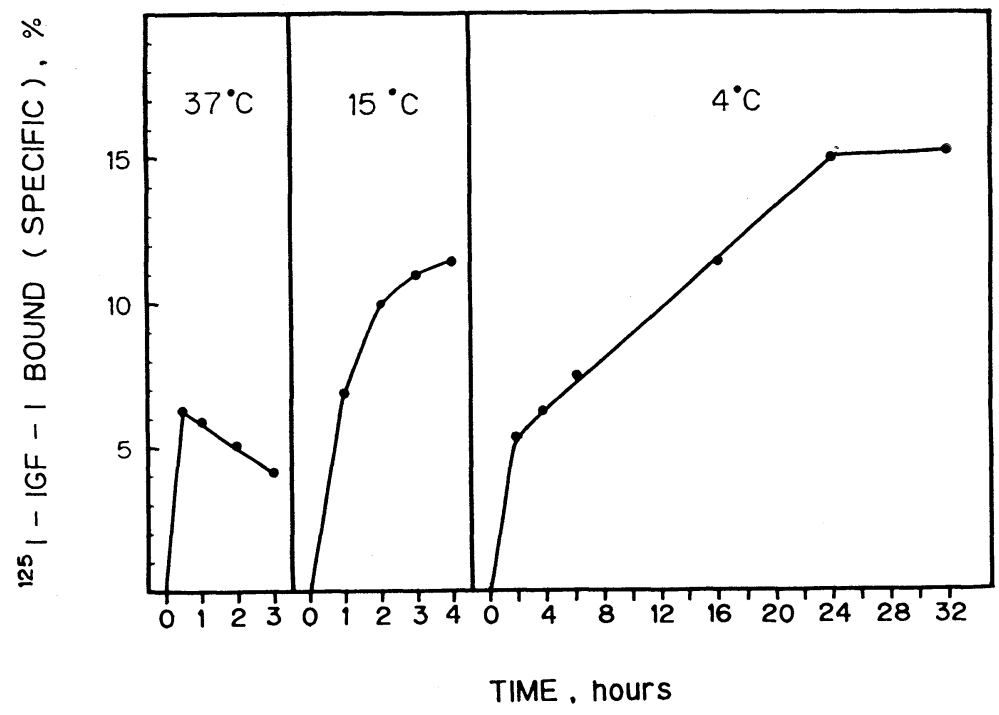

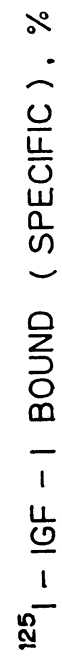

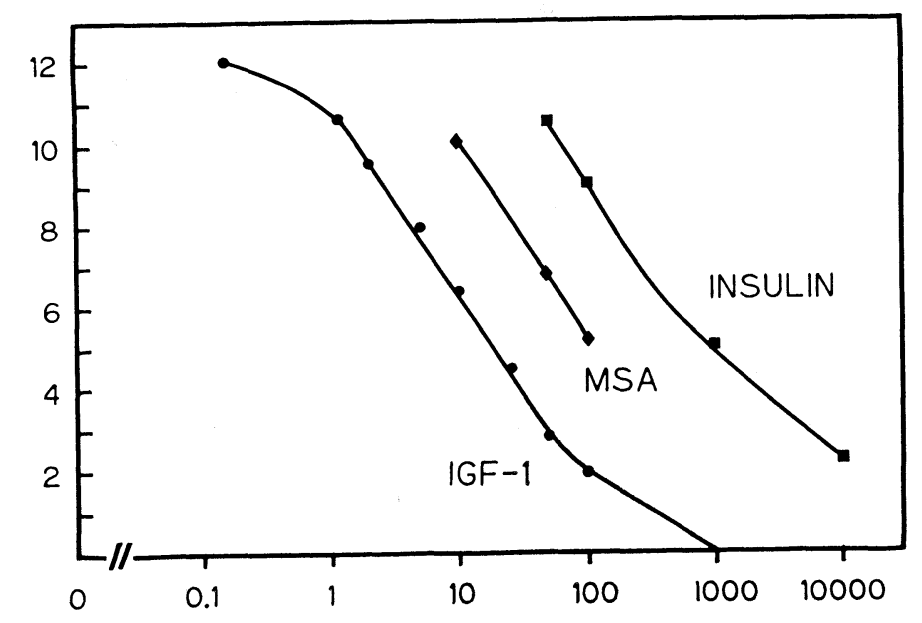

Fig. 2A. Competition for specific [125I]IGF-I binding to the MDCK cells $\left(3.6 \times 10^{6}\right.$ cells $\left./ \mathrm{ml}\right)$ by IGF-I, multiplication stimulating activity (MSA) and porcine insulin. 
ded. The nonspecific binding was less than $15 \%$ of total binding.

\section{Specificity of IGF-I binding}

[ ${ }^{125}$ I]IGF-I binding to the MDCK cells was displaced by unlabeled IGF-I in a dosedependent manner (Fig. 2A). A 50\% inhibition of [ $\left.{ }^{125} \mathrm{I}\right] \mathrm{IGF}-\mathrm{I}$ binding was obtained at a concentration of $10 \mathrm{ng} / \mathrm{ml}$ IGF-I. The Scatchard analysis for this binding revealed a curvilinear pattern (Fig. 2B). Assuming two classes of binding sites, the affinity constant $\mathrm{Ka}$ and the number of binding sites per cell for high affinity binding site were 9.5 $\times 10^{8} \mathrm{M}^{-1}$ and 34,000 , respectively. The binding of [ $\left.{ }^{125} \mathrm{I}\right] \mathrm{IGF}-\mathrm{I}$ to the cells was also displaced by MSA and porcine insulin, with potencies 10 and 100 times less than that of IGF-I, respectively (Fig, 2A). In addition, $\left[{ }^{125} \mathrm{I}\right]$ insulin binding to the cells was minimal, and IGF-I displaced the [ $\left.{ }^{125} \mathrm{I}\right]$ insulin binding with 10 times greater potency than insulin (Fig. 3). When the MDCK cells were cross-linked to [ ${ }^{125}$ I]IGF-I with DSS, solubilized and electrophoresed in the presence of reductant, the major band migrated at $\mathrm{Mr}=130,000$. An excess of unlabeled IGF-I blocked the formation of this band (Fig. 4).

\section{Effect of IGF-I on DNA synthesis}

IGF-I stimulated $\left[{ }^{3} \mathrm{H}\right]$ thymidine incorporation into DNA at a concentration as low as $0.1 \mathrm{ng} / \mathrm{ml}$. Maximal stimulation was observed at $10 \mathrm{ng} / \mathrm{ml}$ IGF-I with the thymidine

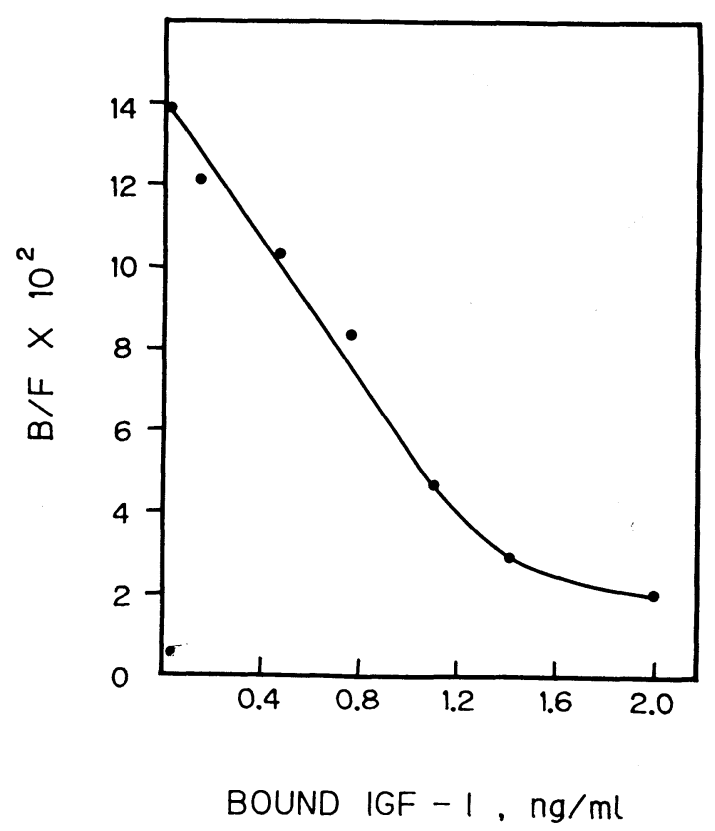

Fig. 2B. Scatchard analysis of $\left[{ }^{125} \mathrm{I}\right] \mathrm{IGF}-\mathrm{I}$ binding to the MDCK cells. $B / F$, Bound to free ratio.

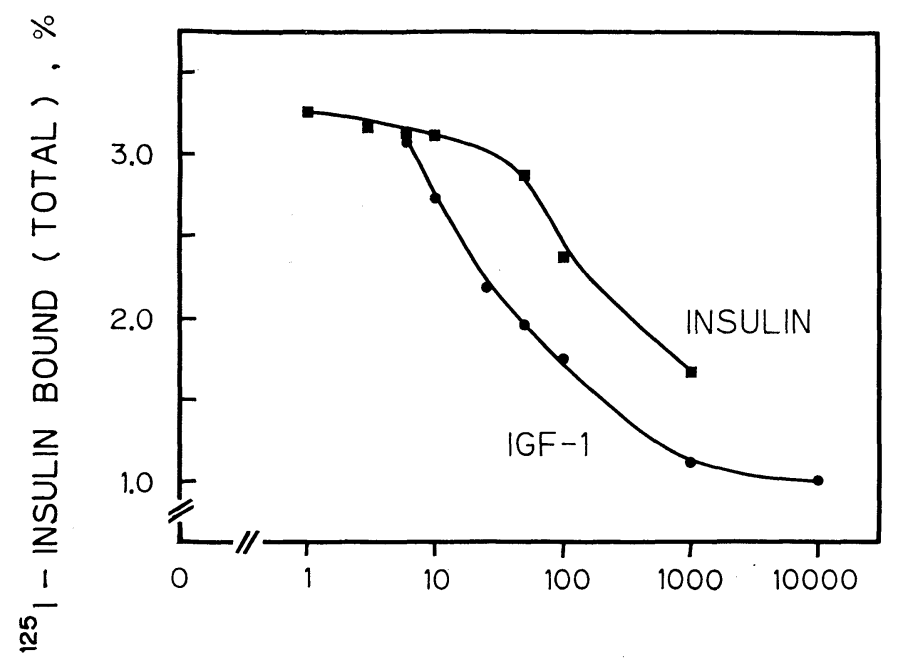

Fig. 3. Competition for total $\left[{ }^{125} \mathrm{I}\right]$ insulin binding to the MDCK cells $\left(1 \times 10^{7}\right.$ cells $\left./ \mathrm{ml}\right)$ by porcine insulin and IGF-I. 


\section{$\mathrm{Mr} \times 10^{-3}$ \\ $200-$ \\ $116-$ \\ 92- \\ $66-$}

\section{unlabeled}

IGF-I

Fig. 4. Cross-linking of $\left[{ }^{125} \mathrm{I}\right]$ IGF-I with MDCK cells.

Left lane: unlabeled IGF-I (-), Right lane: unlabeled IGF-I (+).

incorporation being $260 \%$ of the control (Fig. 5). A half-maximum stimulation was achieved at a concentration of $0.7 \mathrm{ng} / \mathrm{ml}$. On the other hand, insulin $(10 \mu \mathrm{g} / \mathrm{ml})$ had little, if any, effect on DNA synthesis with $118 \%$ of control, while both IGF-I and insulin in maximally effective concentrations had no additive effect (data not shown). 


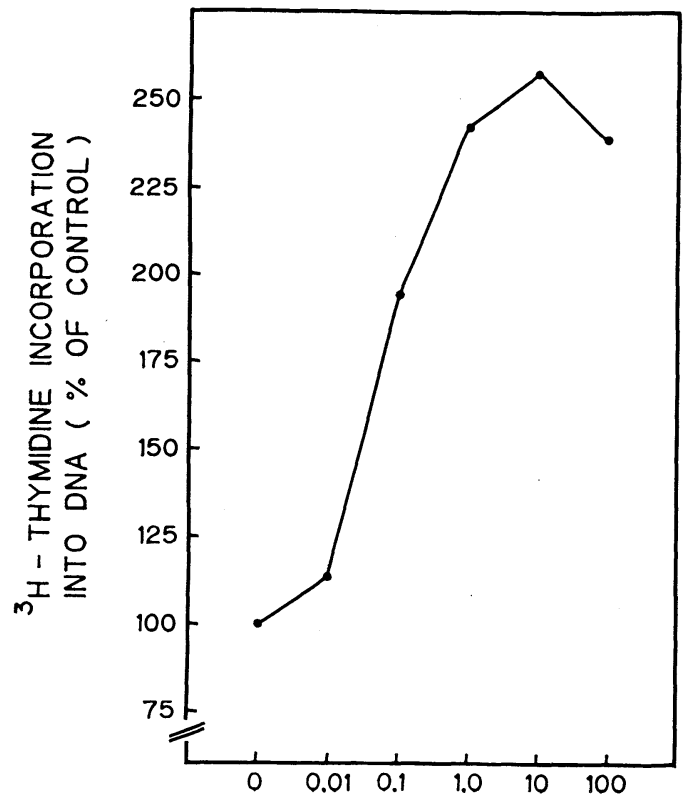

CONCENTRATION OF IGF- I, $\mathrm{ng} / \mathrm{ml}$

Fig. 5. Stimulation of $\left[{ }^{3} \mathrm{H}\right]$ thymidine incorporation into DNA synthesis in MDCK cells $\left(1 \times 10^{5} \mathrm{cells} / \mathrm{ml}\right)$ by IGF-I.

\section{Effect of IGF-I on cell proliferation}

When IGF-I was present in the cell culture with 1\% FCS for two days, the number of cells increased as a function of the concentration of IGF-I (Fig. 6). At $100 \mathrm{ng} /$ $\mathrm{ml}$, the number of cells increased to 162 $\pm 11.6 \%$ (mean \pm SEM, $\mathrm{n}=4$ ) of control. Even at a physiological concentration (1.0 $\mathrm{ng} / \mathrm{ml}$ ), IGF-I significantly stimulated cell proliferation.

\section{Discussion}

In the present study, specific IGF-I receptors on the MDCK cell line were identified and characterized. [ ${ }^{125}$ I]IGF-I specifically bound to the MDCK cells and the binding characteristics were similar to those demonstrated in other cells. Compared to

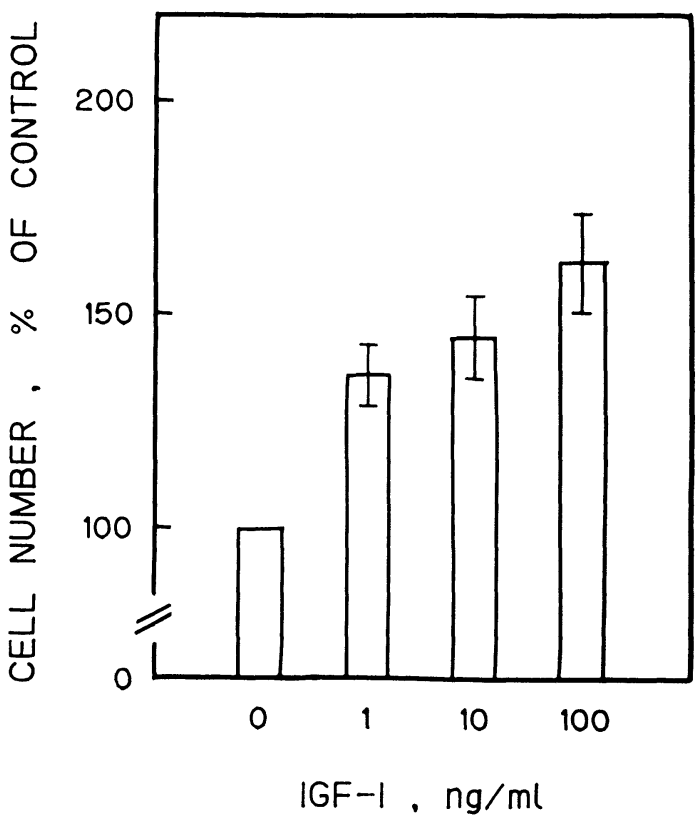

Fig. 6. The number of MDCK cells grown for 2 days in DMEM with $1 \%$ FCS in the presence of various concentrations of IGF-I (0$100 \mathrm{ng} / \mathrm{ml}$ ). Values represent the mean \pm SEM for four experiments.

IGF-I, the relative potencies of MSA and insulin in displacing [ ${ }^{125}$ I]IGF-I binding were 10 and $1 \%$, respectively. The IGF-I binding subunit was $\mathrm{Mr}=130,000$ in an affinity-labeling technique. These results indicate that IGF type I receptors are present in these cells, confirming the previous data of Krett et al. (1986).

In contrast, $\left.{ }^{125} I\right]$ insulin binding to the cells was minimal, and IGF-I inhibited [ ${ }^{125 I}$ ]insulin binding 10 times more than insulin. This result suggests that $\left[{ }^{125} \mathrm{I}\right]$ insulin binds to IGF-I receptor but not to insulin receptor.

At a physiological concentration, IGF-I markedly stimulated DNA synthesis in the MDCK cells and increased the number of cells, indicating that IGF-I binding sites are functionally important in mediating its mitogenic effect. However, insulin even at a pharmacological concentration scarcely 
stimulated DNA synthesis. These data suggest that IGF-I and insulin act on the MDCK cells through IGF type I receptors.

In summary, this study confirms that IGF-I receptors, but not insulin receptors, are present on the MDCK cells, and further demonstrates that the IGF-I has biological effects on the cells. These data imply that the presence of specific IGF-I receptors may be functionally important for the cells and that this cell line may be useful for future studies concerning the interaction between IGF-I and its receptor.

\section{Acknowledgements}

The authors are greatly indebted to Fujisawa Pharmaceutical Co. (Osaka, Japan) for supplying biosynthetic IGF-I.

This work was partly supported by Grants in Aid No. 60770924, No. 58571012, and No. 58440084 for Scientific Research from the Ministry of Education, Science and Culture, Japan, a Research Grant from the intractable Diseases Division, Public Health Bureau, Ministry of Health and Walfare, and a Research Grant from the Foundation for Growth Science in Japan.

\section{References}

Beckner, S. K., F. J. Darfler and M. C. Lin (1985). Induction of glucagon responsiveness in transformed MDCK cells unresponsive to glucagon. Methods Enzym. 109, 356-360.

Boerner, P. and M. H. Saier, Jr. (1985). Hormonal regulation of the system $\mathrm{A}$ amino acid transport adaptive response mechanism in a kidney epithelial cell line (MDCK). J. Cell. Physiol. 122, 316-322.

Eastman, R. C., M. A. Lesniak, J. Roth, P. DeMeyts and P. Gorden (1979). Regulation of receptor by homologous hormone enhances sensitivity and broadens scope of radioreceptor assay for human growth hormone. J. Clin. Endocrinol. Metab. 49, 262-268.

Gambhir, K. K., J. A. Archer and C. J. Bradley (1978). Characteristics of human erythrocyte insulin receptors. Diabetes 27, 701-708.

Hofmann, C., M. Crettaz, P. Bruns, P. Hessel and G. Hadawi (1985). Cellular responses elicited by insulin mimickers in cells lacking detectable plasma membrane insulin receptors. J. Cell. Biochem. 27, 401-414.

Krett, N. L., J. H. Heaton and T. D. Gelehrter (1986). Madin-Darby canine kidney cells display type I and type II insulin-like growth factor (IGF) receptors. Biochem. Byophys. Res. Commun. 134, 120-127.

Laemmli, U. K. (1970). Cleavage of structural protein during the assembly of the head of bacteriophage T4. Nature 227, 680-685.

Lin, M. C., S. M. Koh, D. D. Dykman, S. K. Beckner and T. Y. Shih (1982). Loss and restoration of glucagon receptors and responsiveness in a transformed kidney cell line. Exp. Cell. Res. 142, 181-189.

Lin, M. C., S. K. Beckner and F. J. Darfler (1985). Characterization of hormone-sensitive Madin-Darby canine kidney cells. Methods Enzym. 109, 360-365.

Madin, S. H. and N. B. Darby (1958). Established kidney cell lines of normal adult bovine and ovine origin. Proc. Soc. Exp. Biol. Med. 98, 574-580.

Nissley, S. P. and M. M. Rechler (1984). Insulin-like growth factors: biosynthesis, receptors, and carrier proteins. In: Hormonal proteins and peptides. (C. H. Li ed.). Academic Press, Orland. pp. 128-203.

Niwa, M., S. Sato, Y. Saito, F. Uchiyame, H. Ono, M. Yamashita, T. Kitaguchi, Y. Shiga, J. Notani, H. Yamada, Y. Ishii, I. Ueda and Y. Takagi (1986). Chemical synthesis, cloning and expression of genes for human somatomedin C (insulin-like growth factor I) and ${ }^{59}$ Val-somatomedin C. Annals of the New York Academy of Science, 469, 31-52.

Rindler, M. J., L. M. Chuman, L. Shaffer and M. H. Saier, Jr. (1979). Retention of differentiated properties in an established dog kidney epithelial cell line (MDCK). J. Cell Biol. 81, 635-648.

Roth, J. (1975). Methods for assaying immunologic and biologic properties of iodinated peptide hormones. Methods Enzym. 37, 223-233.

Roth, R. A., B. A. Maddux, K. Y. Wong, Y. Iwamoto and I. D. Goldfine (1981). Insulinricin B chain conjugate. J. Biol. Chem. 256, 5350-5354. 
Zapf, J., M. Mader, M. Waldvogel, D. S. Schalch and E. R. Froesch (1975). Specific binding of nonsuppressible insulinlike activity to chicken embryo fibroblasts and solubilized fibroblast receptor. Arch. Biochem. Biophys. 168, 630637. 